\title{
We're listening
}

\section{Try a textbook listening tour to advance an OER initiative}

I 's little surprise that academic librarians at institutions of every size and type are launching initiatives to encourage instructors to adopt Open Education Resources (OER). Whether these programs offer incentives to faculty or simply promote the benefits of OER and other textbook affordability options, they are a win for students who save money and gain a better learning experience. The textbook affordability movement in higher education also places academic librarians in a new leadership role as they manage campus-wide efforts to promote the benefits of OER. ACRL's “2018 Top Trends in Academic Libraries" report identifies multiple challenges to faculty adoption, such as the lack of OER resources or perceived quality, but that these are also "opportunities for librarians to cultivate partnerships with faculty in the discovery, advocacy and preservation of OER."

How exactly should academic librarians go about creating those opportunities, especially when many faculty are reluctant to give up their textbook and have limited time to entertain librarians who think adopting OER is a great idea?

In response to this challenge, the librarians at Temple University Libraries developed a strategy that takes a different approach. Instead of positioning ourselves as OER sales associates whose task was to sell as much product as possible, we focused on better understanding faculty issues and challenges around the selection of learning materials.
Seeking to connect with faculty on textbook affordability issues in a new way, our library organized a "Textbook Listening Tour." The tour's primary purpose was to meet with department chairs and faculty for frank, judgement-free discussions about textbooks. Though OER advocates are eager to enthusiastically present the case for affordable learning content to faculty, evidence supports the advantages of first listening to others before attempting to influence their thinking. ${ }^{2}$ It is a more empathic approach that leads to an engaged, two-way conversation as opposed to what may come off as a sales pitch. Our experience was that listening intently opened up avenues to new opportunities in academic departments where no prior outreach had occurred.

\section{Plateauing conundrum}

Whatever their level of expertise or understanding of the multitude of textbook affordability strategies and options, academic librarians tread on somewhat precarious ground when it comes to conversations with faculty about instructional materials. While making points about saving students money, presenting research that supports

Steven J. Bell is associate university librarian, email: steven.bell@temple.edu, and Annie Johnson is library publishing and scholarly communications specialist, email: annie.johnson@temple.eduTemple Libraries

(C) 2019 Steven J. Bell and Annie Johnson 
improved learning with OER, and emphasizing the ability to customize learning content may be powerful and appealing to some faculty, academic librarians are ultimately limited in their ability to recommend learning materials, owing to their lack of subject expertise. Once librarians win over the faculty who have already sold themselves on the benefits of OER, textbook affordability initiatives have a tendency to plateau, and encouraging and achieving new adoptions becomes more challenging.

That was the case at Temple University where the librarians launched a textbook affordability project in $2011 .^{3}$ While approximately ten faculty join this incentivebased project annually, adoptions of open textbooks in large enrollment courses or certain disciplines saw limited progress. Our first response to this situation was to push harder to create awareness and seek new avenues to convince faculty that choosing OER over commercial textbooks was the right thing to do. Promotional efforts took the form of occasional articles in the faculty senate newsletter, emails from subject liaison librarians to faculty about new OER material in their discipline, Open Education Week programming such as panels featuring faculty advocates for OER, and behind the scenes efforts to gain assistance from colleagues in other academic support units such as the Teaching and Learning Center.

To an extent, these strategies did help to create awareness. Where they fell short was in encouraging adoption among faculty who find it difficult to give up what we refer to as "the package." Librarians know the package as a textbook with multiple supplements, such as slide decks, multimedia, and assessments. Publishers provide this added content as a powerful hook for faculty, especially those teaching large enrollment courses, where features such as learning management system integration or automated quiz grading are valued timesavers. When OER are unable to replicate these instructional materials, efforts to promote adoption can lead to librarian frustration. These barriers, as well as other commonly accepted OER myths, are difficult to overcome with standard librarian approaches. These challenges led us to seek out a different way to engage faculty in textbook affordability.

\section{Inspiration to try listening instead of talking}

It is a natural inclination for academic librarians to want to tell faculty and students about their incredible resources, knowing full well too few community members take advantage of them. Our mindset about this shifted after hearing a presentation by librarians who sought a radically different approach. Instead of talking, they focused on listening. Organized by the Association of Research Libraries, as part of their Reimagining the Library Liaison project, ${ }^{4}$ a panel held at the 2017 ALA Annual Conference focused on better ways to communicate with faculty. ${ }^{5}$ The big take away from that program was the power of questions. Instead of just telling faculty about the library's resources, the panelists recommended a set of simple open-ended questions to get faculty talking about themselves, their research, students, and any changes in their department. ${ }^{6}$ How could sitting back and listening benefit librarians?

This method's advantage is that it helps to build a trusting relationship, one based on taking an interest in what the other party has to say. In reflecting on this program, Bell wrote:

Changing the dynamic from getting a sale to giving a rewarding experience may help eliminate feelings of failure and rejection when faculty ignore librarians. It's more than an exercise in counting numbers; it's about opening doors to future possibilities."

This approach should resonate with business-adverse academic librarians who find the idea of "selling" faculty on OER offputting. Inspired by this program, it seemed 
well worth a try to engage faculty in conversation about textbooks, the selection of instructional material, and student learning. The next step was to work out the logistics for the listening tour.

\section{Going out on tour}

For a solid foundation for success, we sought the support of our university provost, which our library dean was instrumental in obtaining. That led to a meeting of representatives from the library, the office for undergraduate studies, and the teaching and learning center. While the library took the lead in developing the open-ended questions that would spark our faculty colleagues to share their textbook behaviors and experiences, our academic support colleagues contributed to their development. One thing we were clear about from the beginning is that these tours were not about OER and encouraging adoptions, but rather giving faculty space to talk about their use of textbooks and other learning material.

In the fall of 2017 we piloted our tour with visits to the math department and business school. This led us to refine our questions and the structure of a tour visit. Although we invited our academic support colleagues to attend the tours, they ultimately decided to entrust the visits to us with occasional reporting back to them. That worked to our advantage. We found that too many interviewers asking questions overwhelmed faculty and diminished our effectiveness. The most time-consuming aspect of the textbook listening tour was organizing meetings between three library staff and two or three faculty or chairs. Once scheduled, the tour meetings lasted one hour.

During the spring 2018 semester we conducted six additional tour visits. We met with a mix of department chairs, course coordinators, and faculty. Each visit was informative and provided new insight into how different departments made instructional material decisions and textbook choices. For example, we learned that the physics depart- ment provided students with an elaborate multipage chart with different cost options for the course material. The political science department had already committed to going textbook-free in as many courses as possible and created a Google Team Drive for faulty to share learning content across courses. Other departments were anywhere in between. We found our open-ended questions worked well to initiate and guide the conversation, and that we did indeed mostly listen. In fact, we sometimes had to fight our natural inclination to speak out to make points about our textbook affordability project.

There were two notable unexpected benefits. First, we heard more about faculty already using no-cost learning materials than we anticipated, as well as encountering faculty, or receiving leads, who were interested in turning their own learning material into an open textbook.

One of the most challenging elements of any textbook affordability initiative is knowing what's already happening across the institution. The textbook listening tour was a path to making these discoveries. Second, the tour proved an excellent way to involve subject-specialist librarians with the initiative and textbook affordability, in general. We asked the appropriate departmental subject specialist to join each tour meeting. It was a revelation for the liaisons to hear about textbook behavior in their disciplinary areas, and it sparked their interest in getting engaged with our textbook affordability project. Faculty sharing their frustrations about textbooks and their cost can have that effect.

\section{What we learned}

Our existing Textbook Affordability Project was successful, but primarily library-driven. Achieving longer-term sustainability required broader institutional support and prioritization of textbook affordability. A secondary goal of the tour was to encourage our provost to establish a new university-wide textbook affordability task force. 
So at the end of the spring 2018 semester, we prepared a report for our provost to summarize our findings and share recommendations for a sustainable, institutional approach to textbook affordability. ${ }^{8}$ Some of the key findings from the report were:

- Faculty recognize that textbooks are expensive, and that students are sensitive to the price. Faculty know that a too-large percentage of students do not buy their textbooks.

- Many faculty opt for the "package deal" (expensive textbook plus instructor resources, homework, and test banks), especially for large enrollment courses, where they take advantage of auto-grading support.

- Some departments are already experimenting with open textbooks, while others remain skeptical.

- Faculty who participated in our Teaching and Learning Center's course redesign seminar indicated that the redesign of their course was an optimal time to rethink course learning material and potentially adopt an open textbook or other OER.

Recommendations from the report included:

- Develop a communications strategy aimed at faculty that encourages the adoption of no or low-cost learning content.

- Organize a new Textbook Affordability Committee and charge it to review existing textbook practices' impact on students, and explore new strategies to achieve better, more affordable learning materials.

- Enlist Temple University librarians and Teaching and Learning Center instructional designers to develop opportunities for faculty to become more aware of affordable learning options.

- Conduct an audit of current faculty use of textbooks in order to develop a more robust picture of what learning materials are in use across the curriculum.

\section{It pays to listen}

Perhaps the most valuable lesson learned from our textbook listening tour is that when we listen, we both build stronger relationships and gain deeper insights into our understanding of our colleagues' challenges, inspirations, and hopes for our students. Speaking to faculty about OER is potentially off-putting for academic librarians because it involves effort to convince faculty they need to change, by no means an easy task. As a result, some librarians would prefer to exhaust their limited collections budget to purchase textbooks or put faculty-selected expensive textbooks on reserve, rather than engage in conversations with faculty about textbook affordability.

There's a better way. Instead of avoiding a chat with faculty about learning materials, start by embracing the possibilities that can result from listening to faculty while they talk about their textbook behaviors. As Nilofer Merchant states, "To listen is to pay attention to. Listening means stepping outside one's own interests, to actually want to know more, and to care what others' interests are." ${ }^{\prime \prime}$ This is the essence of the Textbook Listening Tour. It turns the traditional librarian outreach approach on its head, listening instead of telling, to allow instructors to tell us more about themselves. As we have discovered, that opens up a pathway to discovery for us all that will ultimately benefit our students' success.

\section{Notes}

1. ACRL Research Planning and Review Committee, "2018 top trends in academic libraries: A review of the trends and issues affecting academic libraries in higher education," College \& Research Libraries News 79, no. 6 (2018), accessed December 22, 2018, https://crln.acrl.org/index.php/crlnews /article/view/17001/18750.

2. Nilofer Merchant, "To Change Someone's Mind, Stop Talking and Listen," Harvard Business Review, February 6, 2018, accessed December 22, 2018, https://hbr. org/2018/02/to-change-someones-mind-stop -talking-and-listen.

(continues on page 332) 
structure for new open practices and platforms. It is their work that has encouraged funders and institutions to begin signaling change in incentives and research priorities.

\section{Conclusion}

The future holds radical changes for the scholarly landscape, and libraries can play a critical role in the new paradigm shift. Librarians have the established trust of researchers and can help them progress beyond thinking of open as merely access to information.

If open source is people, then librarians are the leaders, helping everyone navigate the bridges and roads to find the route that best fits their needs. The decisions that libraries make individually and collectively about what tools to use and what infrastructure to support-and under what terms-will determine whether we meaningfully address inequities created by legacy academic publishing systems or simply recreate them in new ways. These decisions will shape libraries' role in the scholarly enterprise, now and for the future.

For example, the discovery tools most commonly used by libraries tend to be licensed from commercial vendors, and so are the databases of content they search.
They reflect the inherent biases of those organizations, prioritizing content from the Global North, and rendering invisible a large swath of scholarship not considered to be "mainstream." This is an important reminder that decisions about collections, tools, and metadata are not neutral and have consequences. Libraries should be much more deliberate in questioning these decisions, and challenge existing assumptions before deciding what to buy.

Similarly, infrastructure is often something we notice only when it is broken; and when this happens, we find we don't know who to call. Rather than continuing this dependency, libraries should take on a more active role in creating, supporting, and sustaining the infrastructure we use, to ensure that it truly reflects and supports the values our institutions hold. As library partnerships with publishers, open source platform creators, and discovery tools become more common, we have a unique opportunity to influence the emerging scholarly communication system during the design process, and build an equitable and inclusive system-one that is truly open for all.

\section{Note}

1. http://www.amelica.org/en/. $\not 2$

("We're listening," continues from page 320)

3. Visit http://library.temple.edu/textbook -affordability.

4. See more at https://Www.arl.org /focus-areas/arl-academy/communities-of -practice/reimagining-the-library-liaison.

5. Association of Research Libraries, "Talking So Faculty Will Listen, Listening So Faculty Will Talk: Engagement Strategies for Library Liaisons," ALA Annual Conference, June 26, 2017, accessed January 14, 2019, https://www.arl.org/events/upcoming -events/event/238\#.WfzXXmhyLcs.

6. Martin Tsang, "Faculty Conversation Project Tips," accessed January 14, 2019, https://www.arl.org/storage/documents /Faculty-Conversation-Project-Tips.pdf.

7. Steven J. Bell, "Academic Librarians Have Something to Sell," Library Journal, July 13, 2107, accessed January 14, 2019, https://www.libraryjournal.com/?detailStory=academic-librarians -have-something-to-sell-from-the-bell-tower.

8. The full report, with our question set, is available at https://docs.google. com/document/d/1P5Kn7OGYqEH -jFK4FsSZlomCM6HCsxbO2L_zEzT_E4U/edit.

9. Merchant, "To Change Someone's Mind, Stop Talking and Listen." $\neq 2$ 